\title{
Global scientific trends on aflatoxin research during 1998-2017: a bibliometric and visualized study
}

Sa'ed H. Zyoud ${ }^{1,2,3}$ (D)

\begin{abstract}
Background: Aflatoxins are fungal metabolites associated with contaminated food products. Intake of aflatoxincontaminated food results in serious health hazards and even death. Therefore, the aim of this study is to evaluate the global scientific output of research of aflatoxin by using bibliometric techniques.

Methods: This bibliometric study was conducted using Scopus database and classified the retrieved publications were classified from different aspects, including the countries/region of focus, journals, authors, institutes, citations, and content analysis to discover any hot and emerging topics. In addition, the bibliometric analysis of the international collaborative network and hot research topics were generated by VOSviewer@ software version 1.6.10. The publication period was restricted in the search for two decades (1998-2017).

Results: The search engine of the Scopus database found 9845 documents published in the field of aflatoxin. The USA is the top publishing source in the world (22.85\%), followed by China (11.85\%), India (9.32\%), and Italy (5.25\%). In earlier years, researchers focused on terms related to the topics of "sources and biosynthesis of aflatoxin", "health effects by aflatoxin", and "detoxification and treatment of aflatoxin". However, in recent years, researchers pay more attention to the topic of detection and quantification of aflatoxin.

Conclusions: The quantity of research in global aflatoxin has substantially increased over the past two decades. The evaluation of the historical status and development trend in aflatoxin scientific research can guide future research, and ultimately provide the basis for improving management procedures for governmental decisions, healthcare, industries, and educational institutions.
\end{abstract}

Keywords: Aflatoxin, Scopus, Bibliometric, VOSviewer

\section{Background}

Aflatoxins are toxic secondary metabolites, affected by fungal species, of Aspergillus molds that are largely distributed in nature and have contaminated the food supplies of animals and humans, resulting in serious health hazards and even death $[1,2]$. Additional health impacts of aflatoxins include hepatotoxicity, teratogenicity, genotoxicity, and cytotoxicity [3]. It has been estimated about 5 billion people globally are particularly affected by exposed to dietary aflatoxins [4]. Tropical and subtropical

\footnotetext{
Correspondence: saedzyoud@yahoo.com
}

${ }^{1}$ Poison Control and Drug Information Center (PCDIC), College of Medicine and Health Sciences, An-Najah National University, Nablus 44839, Palestine ${ }^{2}$ Department of Clinical and Community Pharmacy, College of Medicine and Health Sciences, An-Najah National University, Nablus 44839, Palestine Full list of author information is available at the end of the article areas of the world are the highest areas for aflatoxin contamination of the food products, where food storage conditions for cereals (e.g. maize and peanuts), spices, and milk are suboptimal [4-6].

Bibliometrics and evaluation of research performance have been carried out on a wide range of health topics [7-15], and several have been carried out in the fields of environmental studies [16, 17], and toxicology [18-24]. Yet, to the best of my knowledge, only a few bibliometric studies in food contamination have been done recently [25-28], and only one bibliometric study explicitly focused on aflatoxin has been published by using Web of Science (WoS) database for data collection [28]. Because the aflatoxin bibliometric study [28] found that aflatoxin research is now being given increased scientific attention

(C) The Author(s). 2019 Open Access This article is distributed under the terms of the Creative Commons Attribution 4.0 International License (http://creativecommons.org/licenses/by/4.0/), which permits unrestricted use, distribution, and 
internationally, it is therefore necessary to thoroughly evaluate and classify the existing literature from different aspects, including the countries/region of origin, journals, authors, institutes, citations, and content analysis to discover any hot and emerging topics using a large and comprehensive database. Therefore, the aim of this study is to evaluate the global scientific output of research of aflatoxin by using bibliometric techniques, and flag areas of concern.

Identifying the most productive and influential research, can be useful to anyone involved on the field of aflatoxin. Drawing on these insights may aid understanding of historical progress in aflatoxin research over the last 20 years and offer guidance researchers, and policy makers, regarding best scientific and publishing practices for future health research of this scientific field.

\section{Methods}

\section{Data source}

In this bibliometric study, we selected documents related to aflatoxin indexed in Scopus database from 1998 to 2017. This database is the large one, when compared with PubMed or Web of Science, and usually respected as a reliable source for academic and bibliometric studies $[29,30]$. The use of Scopus as a bibliometric tool was based on the idea that it has a better coverage of journals than other databases such as Web of Science [29, 30]. Additionally, Scopus has been used and validated in previously published bibliometric analyses $[8,9,18,31-$ 37]. Data were collected in March 2019.

\section{Search strategy}

The following search string was used to identify publications in the field of aflatoxin based on their titles and/or abstract: TITLE-ABS (aflatox*) AND PUBYEAR >1997 AND PUBYEAR <2018. To get greater accuracy in the findings, the search strategy for the terms related to aflatoxin was limited to Title/Abstract only because if expanded to other search fields such Keywords, many publications identified were not related to aflatoxin (i.e false-positive data). Researchers' experience $[7,35,38$, 39 ] is that inclusion of search items in the title/abstract instead of a topic search (title, abstract, and keywords greatly increases specificity with minimum loss of sensitivity. The major reason for the generation of falsepositive results by keyword search is that Scopus considers Keywords as author and indexed keywords such as "EMTRE drug terms", "EMTREE medical terms", and "Medline keywords".

\section{Bibliometric analysis}

The evaluation of the collected sample involved weighing the following indictors: (1) publication output by years, (2) top 10 countries with their h-index and collaboration pattern, (3) top 10 most influential journals with their Source Normalized Impact per Paper (SNIP), and impact factors (IF), (4) top 10 most influential institutions, and (5) top 20 cited publications.

\section{Visualized analysis}

The bibliometric analysis of the international collaborative network and hot research topics were generated by VOSviewer@ software version 1.6.10 [40]. This freely available computer program (www.vosviewer.com) that is used for constructing and viewing bibliometric maps to analyze the output of countries, and authors in this sphere, and it highlights commonly used terms in the titles and abstracts for the retrieved publications, revealing those hot research topics.

\section{Results and discussion}

The search engine of the Scopus database found 18,342 documents published in the field of aflatoxin from 1963 to 2018 (Additional file 1). The first publications appeared in 1963 [41-43]. After this, the number of publications grew gradually and slowly each year, with little fluctuation (Additional file 1). Of them, 9845 documents published in the field of aflatoxin from 1998 to 2017. Within this batch, this study juggled 8288 articles, 687 reviews, and 870 other types of documents, including letters, article end notes, editorials, and minutes of meetings. Figure 1 shows the publication trend related to aflatoxin from 1998 to 2017. The results reveal that the number of annual publications had gradually increased during 1998-2004, indicating that research output showed steady growth during those years. Prominently, the number of relevant publications increased sharply since 2004; meanwhile, 2017 netted the largest haul of aflatoxin research (850 documents published). The data indicates indeed that issues related to aflatoxin are becoming increasingly important in the investigation of food safety and human health. English is the predominant language of publications on aflatoxin, constituting $93.8 \%$ of the total, with only $6.2 \%$ of the publications in another language. The most common non-English language is Chinese, which constitutes $2.1 \%$ of the total, followed by Portuguese $(0.8 \%)$. The reason for this finding is that Scopus has a better coverage of English language journal than those in other languages [44]. A previously published study on aflatoxin [28] had shown different results (5122 documents worldwide from 1963 to 2016) from those presented in the current study. The difference was due to (1) different databases used to retrieve the documents and (2) research domains being investigated. The study by Klingelhöfer et al. [28] was conducted using WoS and was limited to biomedical research areas. In the current study, Scopus database was 


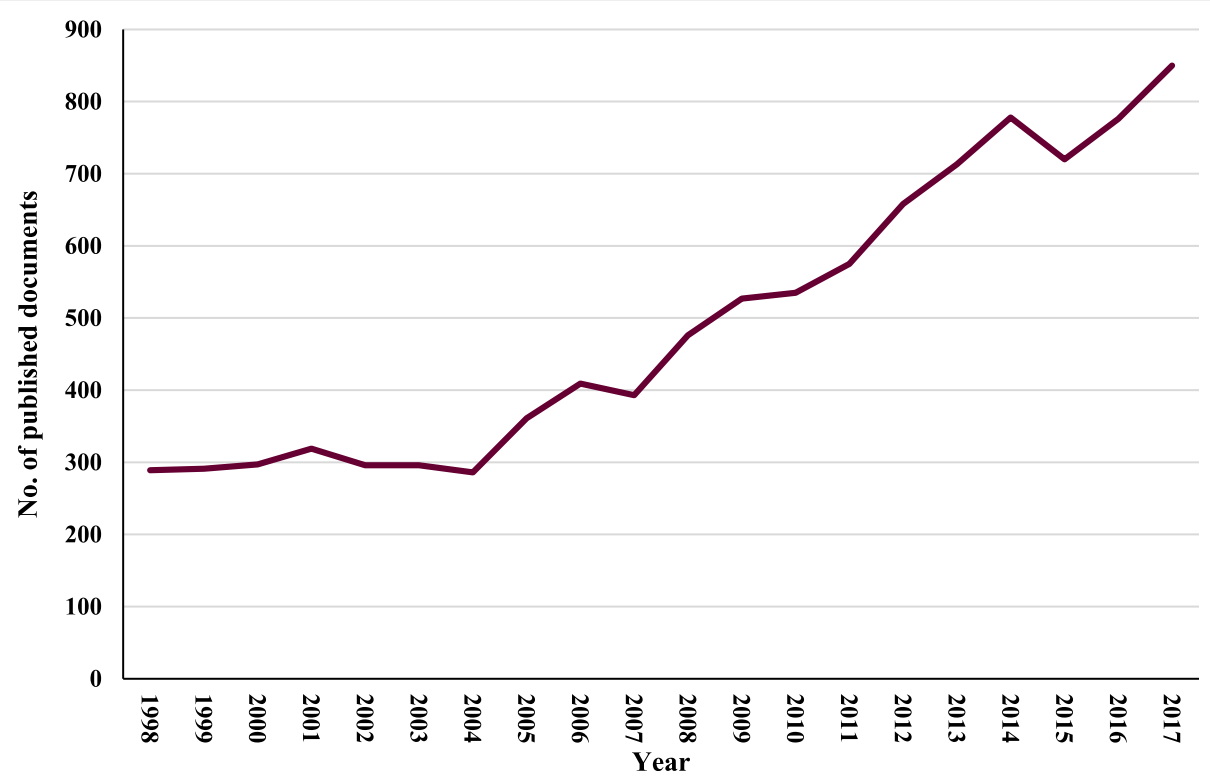

Fig. 1 Number of publications per year (1998-2017)

used without limiting the results to any particular research area.

The top 10 countries of origin are shown in Table 1 , which published 7348 documents $(74.63 \%)$ of all publications. The USA is the leader (22.85\%), followed by China (11.85\%), India (9.32\%), and Italy (5.25\%). Consistent with other previous bibliometric studies [20, 21, $23,28,45]$, most of the publications in the field of aflatoxin research were published in the United States. As the USA is at the forefront of scientific research and academics, and hence, this trend is expected and in line with other bibliometrics [46]. A possible explanation for these results may be due to large part of efforts by the Maryland-based National Institutes of Health (NIH) funding for aflatoxin research, which was granted authority when several outbreaks of human illness caused by aflatoxins had been reported in some developing countries [47-51]. China is the second prolific producer in this field with $11.85 \%$ of the world total publications. It seems possible that these results are due to large part of efforts by the Beijing-headquartered $\mathrm{Na}$ tional Natural Science Foundation of China (NSFC) funding for aflatoxin research [52]. Hence, Chinese authorities might be responding to the emerging problems arising from the rises in deaths from hepatocellular carcinoma which seem related to an increase in aflatoxin contamination of Chinese staple foods and this might have made Aflatoxin research a high and growing priority in China [53].

Among the top 10 countries, five (i.e. India, Iran, Brazil, Turkey, and Egypt) were developing countries as defined by the United Nations, which suggests that each perceive this issue as a serious problem. Among this grouping, there was international diversity not associated

Table 1 Top 10 most productive countries for aflatoxin research

\begin{tabular}{|c|c|c|c|c|c|}
\hline Ranking & Country & Number of publications (\%) & h-index & No of collaboration countries & No of documents from collaboration \\
\hline $1 s t$ & United States & $2250(22.85)$ & 118 & 87 & 810 \\
\hline 2nd & China & $1167(11.85)$ & 67 & 43 & 284 \\
\hline $3 r d$ & India & $918(9.32)$ & 54 & 46 & 126 \\
\hline 4 th & Italy & $517(5.25)$ & 62 & 54 & 180 \\
\hline 5 th & Iran & $505(5.13)$ & 40 & 25 & 73 \\
\hline 6th & Brazil & $494(5.02)$ & 46 & 40 & 145 \\
\hline 7 th & Turkey & $442(4.49)$ & 44 & 20 & 44 \\
\hline 8th & United Kingdom & $372(3.78)$ & 66 & 63 & 240 \\
\hline 9th & Egypt & $364(3.70)$ & 39 & 36 & 143 \\
\hline 10th & Japan & 319 (3.24) & 49 & 33 & 120 \\
\hline
\end{tabular}


with the traditional researching nations' scientific productivity ranking [18, 34-36, 54-56]. The current data verified that Turkey, Egypt and Iran have been the main research contributors from the Middle Eastern countries. Consecutive outbreaks of acute aflatoxicosis in developing countries $[4,6,57]$ (specifically, Turkey $[58,59]$, Iran [60], India [61-64], Brazil [51, 65], and Egypt [66]) caused exceptionally large morbidity and mortality connected with such outbreaks [1, 67-69], and this may explain why more research has emphasized on aflatoxin since that time [28].

Analysis of international collaborations (i.e., link strength) showed that the United States had the highest number of collaborators $(n=87)$ followed by the United Kingdom $(n=63)$, and Italy $(n=54)$ (Fig. 2 and Table 1$)$. The h-index, or Hirsch index, has been demonstrated for each country in Table 1, and it is a measure that combines both the productivity (number of publications) and their citations (perceived as an index of research quality) [70].

Figure 3 illustrates the network visualization map for author collaboration, showing 149 authors with more than 20 documents published. Approximately 23,224 unique authors participated in publishing the retrieved publications, an average of 2.36 authors per publication.
D. Bhatnagar was the most active author with 118 publications. The top 10 journals that published on this topic are listed in Table 2. Food Control published the highest number of articles (384, 3.90\%), followed by Food and Chemical Toxicology (158, 1.60\%) and Toxins (158, $1.60 \%)$. The top 10 journals with the greatest contribution to aflatoxin research accounted for $16.70 \%$ of all publications included in this study.

The analysis of the 20 most cited publications in the last 2 decades (Table 3 ) revealed that there is no close relationship between the number of citations from a specific publication and the most active journals in the area. HS Hussein and JM Brasel's "Toxicity, metabolism, and impact of mycotoxins on humans and animals" published in 2001 in the journal Toxicology is considered the most highly cited aflatoxin piece in all of Scopus. The most cited article on aflatoxin was published by Toxicology, which was not listed in the top 10 journals. Characteristics of the top 20 most-cited publications on aflatoxin [5, 71-89] are presented in Table 3. Although it is difficult to demonstrate the quality or influence of publications by bibliometric analysis, the number of article citations can indicate the value and significance of the journal to some extent [90]. In addition, such analyses for the top 20 most-cited titles can help guide

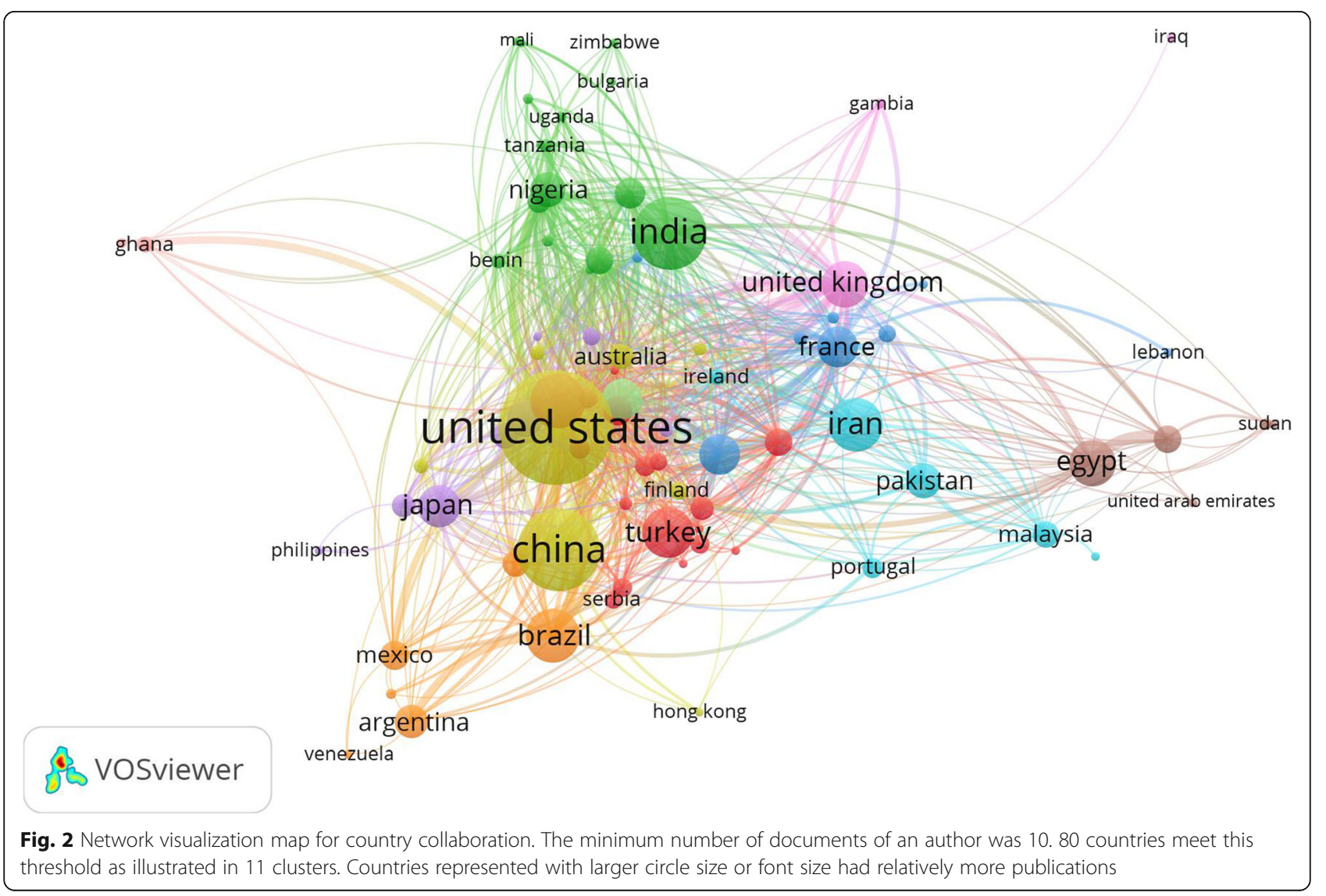




\section{dalcero a.m.}

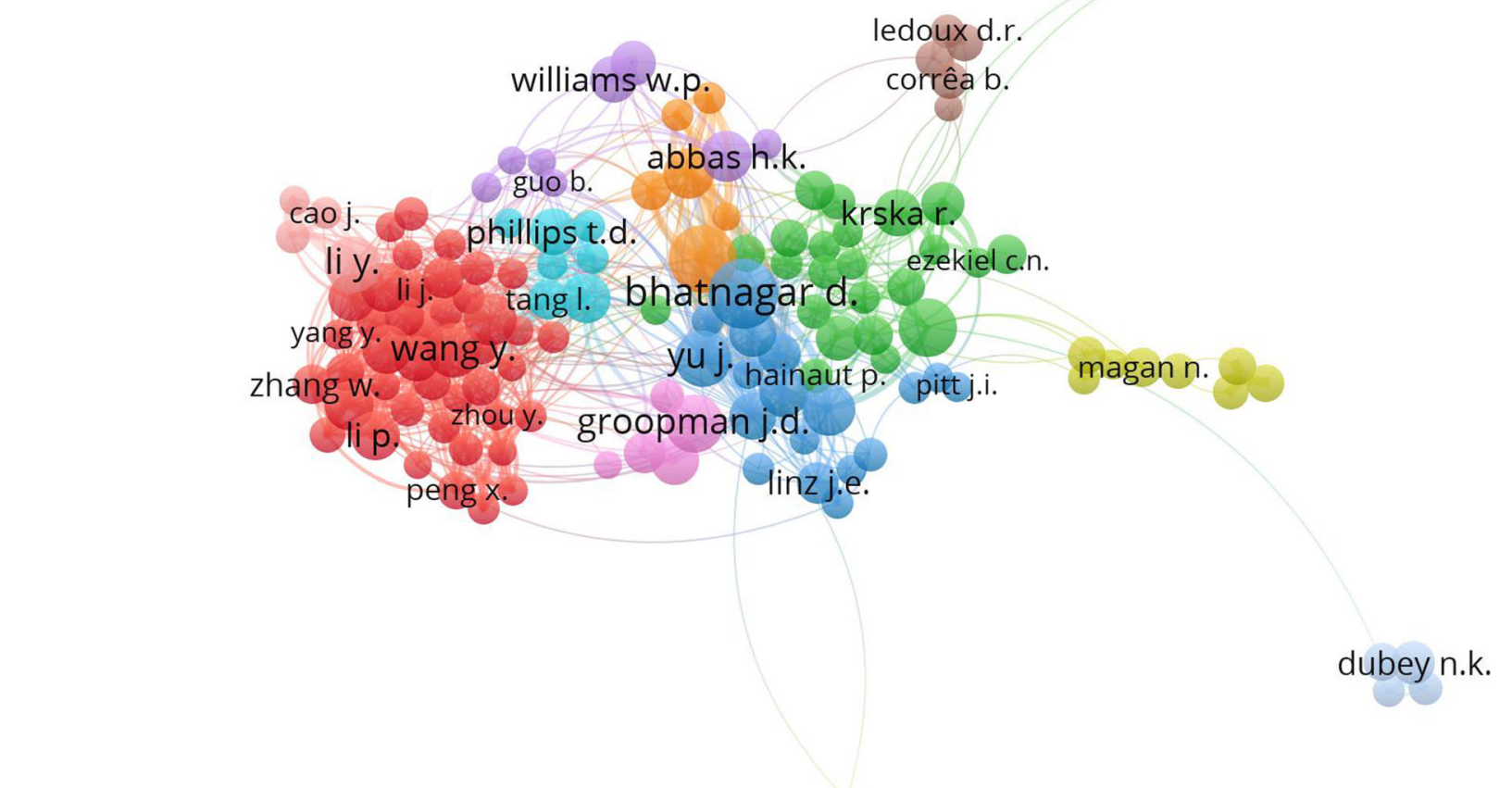

\section{sos Vosiewer}

razzaghi-abyaneh $\mathrm{m}$.

Fig. 3 Network visualization map for author collaboration. The minimum number of documents of an author was 20. Of 23,224 authors, 149 meet this threshold as illustrated in 13 clusters. Authors represented with larger circle size or font size had relatively more publications

Table 2 Most influential journals publishing aflatoxin research

\begin{tabular}{|c|c|c|c|c|}
\hline Ranking $^{a}$ & Journal & Number of publications (\%) & $\mathrm{IF}^{\mathrm{b}}$ & SNIPC \\
\hline $1 s t$ & Food Control & $384(3.90)$ & 4.248 & 1.731 \\
\hline 2nd & Food and Chemical Toxicology & $158(1.60)$ & 3.775 & 1.277 \\
\hline 2nd & Toxins & $158(1.60)$ & 3.895 & 1.245 \\
\hline 4th & Mycotoxin Research & $151(1.53)$ & 3.741 & 1.187 \\
\hline 5 th & Food Additives and Contaminants: Part A & $146(1.48)$ & 2.170 & 0.909 \\
\hline 5 th & International Journal of Food Microbiology & $146(1.48)$ & 4.006 & 1.556 \\
\hline 7th & Journal of Agricultural and Food Chemistry & $143(1.45)$ & 3.571 & 1.321 \\
\hline 8th & World Mycotoxin Journal & $140(1.42)$ & 2.406 & 0.840 \\
\hline 9th & Journal of Food Protection & $115(1.17)$ & 1.559 & 0.744 \\
\hline 10th & Food Additives and Contaminants ${ }^{d}$ & $103(1.05)$ & NA & 1.355 \\
\hline
\end{tabular}

SNIP Source Normalized Impact per Paper, IF Impact factor, NA Not available

${ }^{a}$ Equal journals have the same ranking number, and then a gap is left in the ranking numbers

${ }^{b}$ Impact factors (IF) based on Journal Citation Reports (JCR) 2018 from Clarivate Analytics

'SNIP based on Scopus data which was freely available at www.scopus.com/sources

${ }^{d}$ Continued as: Food Additives \& Contaminants: Part A (2008 - current), and Food Additives \& Contaminants: Part B: Surveillance (2008 - current) 
Table 3 Top-cited papers in the Journal from 1998 through 2017 according to the number of citations in Scopus

\begin{tabular}{|c|c|c|c|c|c|c|}
\hline Rank & Authors & Title & Year & Source title & $\begin{array}{l}\text { Cited } \\
\text { by }\end{array}$ & Document type \\
\hline $1 s t$ & $\begin{array}{l}\text { Hussein and } \\
\text { Brasel [71] }\end{array}$ & $\begin{array}{l}\text { "Toxicity, metabolism, and impact of mycotoxins } \\
\text { on humans and animals" }\end{array}$ & 2001 & Toxicology & 868 & Review \\
\hline 2nd & Williams et al. [5] & $\begin{array}{l}\text { "Human aflatoxicosis in developing countries: A } \\
\text { review" of toxicology, exposure, potential health } \\
\text { consequences, and interventions" }\end{array}$ & 2004 & $\begin{array}{l}\text { American Journal of } \\
\text { Clinical Nutrition }\end{array}$ & 822 & Review \\
\hline $3 r d$ & Bosch et al. [72] & "Epidemiology of primary liver cancer" & 1999 & Seminars in Liver Disease & 796 & Article \\
\hline 4th & Machida et al. [73] & $\begin{array}{l}\text { "Genome sequencing and analysis of } \\
\text { Aspergillus oryzae" }\end{array}$ & 2005 & Nature & 747 & Article \\
\hline 5 th & Creppy [74] & $\begin{array}{l}\text { "Update of survey, regulation and toxic effects } \\
\text { of mycotoxins in Europe" }\end{array}$ & 2002 & Toxicology Letters & 692 & $\begin{array}{l}\text { Conference } \\
\text { Paper }\end{array}$ \\
\hline 6th & Bosch et al. [75] & "Epidemiology of hepatocellular carcinoma" & 2005 & Clinics in Liver Disease & 653 & $\begin{array}{l}\text { Conference } \\
\text { Paper }\end{array}$ \\
\hline 7th & Placinta et al. [76] & $\begin{array}{l}\text { "A review of worldwide contamination of cereal } \\
\text { grains and animal feed with Fusarium mycotoxins" }\end{array}$ & 1999 & $\begin{array}{l}\text { Animal Feed Science } \\
\text { and Technology }\end{array}$ & 619 & Article \\
\hline 8th & Lunn et al. [77] & $\begin{array}{l}\text { "XRCC1 polymorphisms: effects on aflatoxin } \\
\text { B1-DNA adducts and glycophorin A variant } \\
\text { frequency" }\end{array}$ & 1999 & Cancer Research & 513 & Article \\
\hline 9th & Okuda [78] & "Hepatocellular carcinoma" & 2000 & Journal of Hepatology & 510 & Article \\
\hline 10th & $\begin{array}{l}\text { Whittaker et al. } \\
\text { [79] }\end{array}$ & $\begin{array}{l}\text { "The role of signaling pathways in the } \\
\text { development and treatment of } \\
\text { hepatocellular carcinoma" }\end{array}$ & 2010 & Oncogene & 506 & Article \\
\hline 11th & El-Serag [80] & $\begin{array}{l}\text { "Hepatocellular carcinoma: An epidemiologic } \\
\text { view" }\end{array}$ & 2002 & $\begin{array}{l}\text { Journal of Clinical } \\
\text { Gastroenterology }\end{array}$ & 501 & $\begin{array}{l}\text { Conference } \\
\text { Paper }\end{array}$ \\
\hline 12 th & Richard [81] & $\begin{array}{l}\text { "Some major mycotoxins and their } \\
\text { mycotoxicoses-An overview" }\end{array}$ & 2007 & $\begin{array}{l}\text { International Journal of } \\
\text { Food Microbiology }\end{array}$ & 475 & Article \\
\hline 13th & Yu et al. [82] & $\begin{array}{l}\text { "Clustered Pathway Genes in Aflatoxin } \\
\text { Biosynthesis" }\end{array}$ & 2004 & $\begin{array}{l}\text { Applied and Environmental } \\
\text { Microbiology }\end{array}$ & 453 & Short Survey \\
\hline 14th & Turner et al. [83] & $\begin{array}{l}\text { "Analytical methods for determination of } \\
\text { mycotoxins: A review" }\end{array}$ & 2009 & Analytica Chimica Acta & 447 & Review \\
\hline 15th & D’Mello et al. [84] & $\begin{array}{l}\text { "Fusarium mycotoxins: A review of global } \\
\text { implications for animal health, welfare } \\
\text { and productivity" }\end{array}$ & 1999 & $\begin{array}{l}\text { Animal Feed Science and } \\
\text { Technology }\end{array}$ & 433 & Article \\
\hline 16th & McMahon [85] & $\begin{array}{l}\text { "The natural history of chronic hepatitis } \\
\text { B virus infection" }\end{array}$ & 2009 & Hepatology & 423 & Article \\
\hline 17 th & Peraica et al. [86] & "Toxic effects of mycotoxins in humans" & 1999 & $\begin{array}{l}\text { Bulletin of the World Health } \\
\text { Organization }\end{array}$ & 414 & Article \\
\hline 18th & Gomaa et al. [87] & $\begin{array}{l}\text { "Hepatocellular carcinoma: Epidemiology, } \\
\text { risk factors and pathogenesis" }\end{array}$ & 2008 & $\begin{array}{l}\text { World Journal of } \\
\text { Gastroenterology }\end{array}$ & 410 & Article \\
\hline 19th & Key et al. [88] & "Diet, nutrition and the prevention of cancer" & 2004 & Public Health Nutrition & 402 & Review \\
\hline 20th & Geiser et al. [89] & $\begin{array}{l}\text { "Cryptic speciation and recombination in } \\
\text { the aflatoxin-producing fungus } \\
\text { Aspergillus flavus" }\end{array}$ & 1998 & $\begin{array}{l}\text { Proceedings of the National } \\
\text { Academy of Sciences of the } \\
\text { United States of America }\end{array}$ & 396 & Article \\
\hline
\end{tabular}

researchers and toxicologists towards up-to-date knowledge of the current trends in basic research, the changing landscape in food safety, and significant future research directions [91].

The network visualisation term map for aflatoxin research undertaken globally over the 20-year period from 1998 to 2017 is shown in Fig. 4a. One hundred twentyeight thousand four hundred twenty different terms were found from the collected publications; however, only 1243 of them appeared more than 40 times. In the term map (Fig. 4a), four thematic research clusters or areas can be noticed, consisting of 1243 co-occurring terms categorising the aflatoxin research field with different four colors. The terms with similarity in research topics are grouped together and the 4 clusters were analyzed as follows:

- Cluster 1 (in red color): this cluster mainly includes the terms related to the topic of detection and quantification of aflatoxin, such as "sample", 

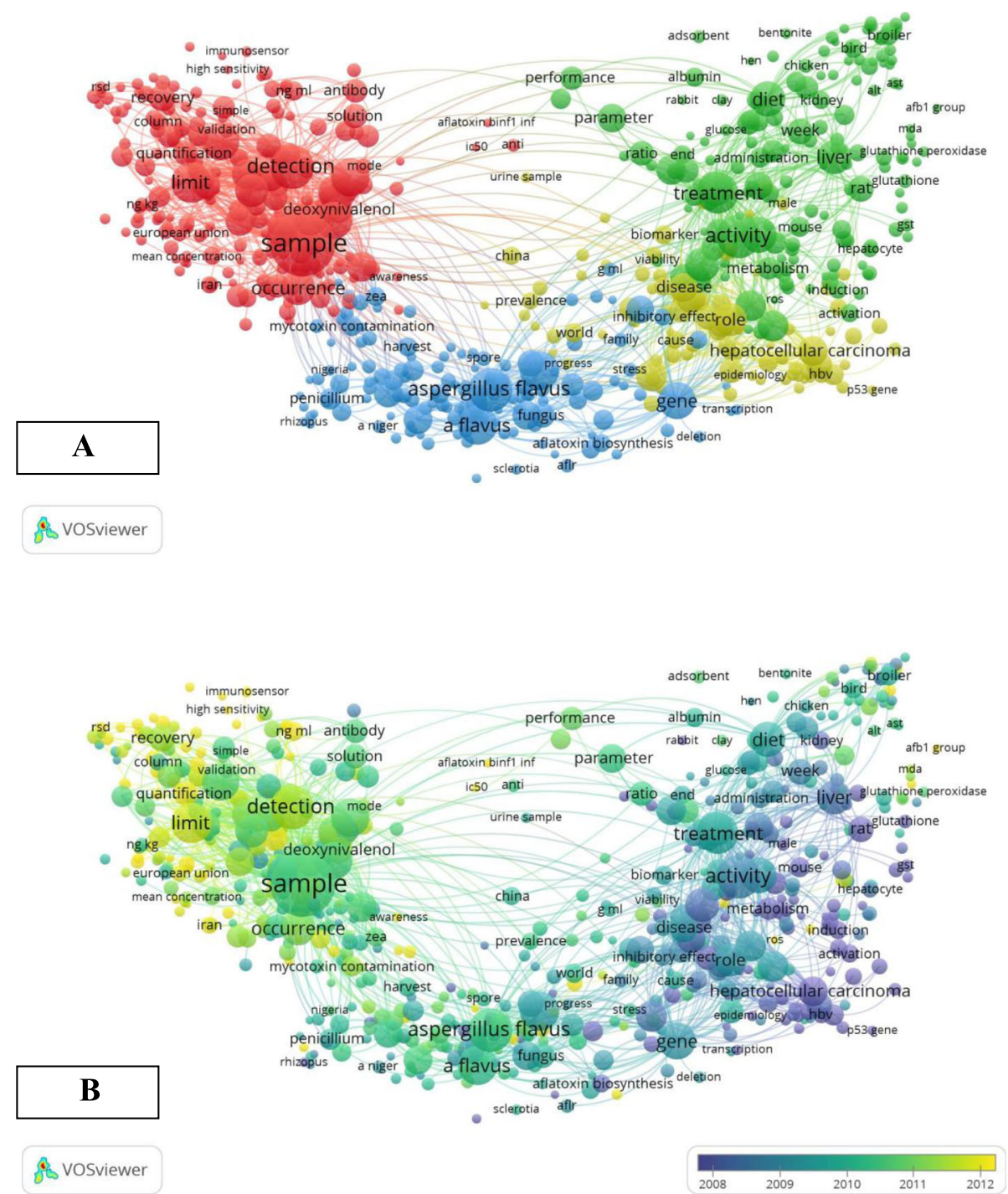

Fig. 4 VOSviewer co-occurrence term map of title and abstract words in aflatoxin publications during 1998-2017. a The network visualisation term map for aflatoxin research undertaken globally over the 20-year period. $\mathbf{b}$ Distribution of terms according to the mean frequency of appearance; terms in blue appeared earlier than those in yellow colored terms appeared later

"detection", "solution"; "validation", "antibody", "quantification", "immune sensor", and "column".

- Cluster 2 (in blue color): this cluster mainly includes the terms related to the topic of sources and biosynthesis of aflatoxin, such as "Aspergillus flavus", "A. flavus", "spore", harvest", "fungus", "mycotoxin contamination", and "biosynthesis".

- Cluster 3 (in yellow color): this cluster mainly includes the terms related to the topic of health effects by aflatoxin, such as "hepatocellular carcinoma", "disease", "effect", "gene", and "biomarker".

- Cluster 4 (in green color): this cluster mainly includes the terms related to the topic of detoxification and care regarding aflatoxin, such as "treatment", "administration", "diet", glutathione" and "induction".

The color of terms was coded by VOSviewer, based on the average time they appeared in the 9845 related publications (Fig. 4b). The blue color indicates the keyword appeared early and red indicates the keywords appeared later. Before 2010, namely in the early stage of research, most aflatoxins' studies focused on terms related to the topics of "sources and biosynthesis of aflatoxin", "health effects by aflatoxin", and "detoxification and treatment of aflatoxin". The latest trends showed that the terms related to the topic of detection and quantification of aflatoxin would be of concern widely in the future. 
One clear theme to emerge from the findings is that the most top-cited aflatoxin publications emphasised the diversity of sub-topics similar to the research hotspots from co-occurring terms including "health effects by aflatoxin" [5, 71, 72, 75, 77, 78, 80, 84-87], "sources and biosynthesis of aflatoxin" [76, 81, 82, 89], "detoxification and treatment of aflatoxin" $[74,79,88]$, and "detection and quantification of aflatoxin" [73, 83].

The top ten most prolific institutions in the field of aflatoxin research across the period 1998-2017 are shown in Table 4. USDA Agricultural Research Service, of Washington $\mathrm{DC}$, published highest number of aflatoxin publications with 508 documents and covered $5.16 \%$ of the total literature. Although the United States led the index, with 6 institutes, there was one institution, respectively, from Argentina, China, Egypt, and Brazil. It is noteworthy that in line with the current findings, previous studies have demonstrated that the USDA is among the bodies with the largest number of works on ecosystem research in several previous studies [92-96].

\section{Limitations}

This study utilizes a bibliometric approach to analyze the current status and trend of development of aflatoxin research. But there were a few limitations within which are similar to previous studies. First, the current study was limited by the use of the search term "aflatoxin" in title and/or abstract search only. Particularly, any publications that used "aflatoxin" as a keyword or inside of the publication may have been missed in this analysis. However, if such falsenegative results did exist, they will have little effect on the overall findings [7, 35, 38, 39]. Second, it surveyed just the publications in the Scopus database. Although Scopus is the most frequently used and trusted search engine, a few outlier publications might not have been included. Despite that, the current bibliometric study characterises the first concise analysis of the global publications related to aflatoxin by using Scopus and VOSviewer $\odot$ and illustrates the benefits of bibliometric analysis for assessing research productivity in the field of aflatoxin in a standardised way. Third, the standardization of author names, and terms were completed based on findings on the VOSviewer@ and may not be accurate because in certain cases, some authors might have different name spelling or more than one name. This might generate inaccurate research output for these authors. Despite these limitations, this study provides a relatively solid global view on aflatoxin research from these recent two decades.

\section{Conclusions}

The main purpose of this study was to present an overview on the past, present and future scientific research directions of the research field of aflatoxin by combining a bibliometric analysis with a literature review. The quantity of global research output on aflatoxin has substantially increased over the past 20 years, accounting for more than 9800 publications on relevant journals. In earlier years, researchers focused on terms related to the topics of "sources and biosynthesis of aflatoxin", "health effects by aflatoxin", and "detoxification and treatment of aflatoxin". In recent years, researchers paying more attention to the topic of detection and quantification of aflatoxin would be concerned widely with the future. The USA was the largest contributor to aflatoxin scientific research and had the leading position in global research in this field, followed by China. Quite different from other research domains, some developing economies such as India, Iran, Brazil, Turkey, and Egypt were also

Table 4 The performance of the top 10 most productive institutions in aflatoxin research

\begin{tabular}{lll}
\hline Ranking $^{\text {a }}$ & Institute, country & Number of publications (\%) \\
\hline 1st & USDA Agricultural Research Service, Washington DC, USA & $508(5.16)$ \\
2nd & United States Department of Agriculture, USA & $404(4.10)$ \\
3rd & USDA ARS Southern Regional Research Center, USA & $278(2.82)$ \\
4th & North Carolina State University, USA & $144(1.46)$ \\
5th & Universidad Nacional de Rio Cuarto, Argentina & $134(1.36)$ \\
6th & Universidade de Sao Paulo - USP, Brazil & $126(1.28)$ \\
6 th & Texas A and M University, USA & $126(1.28)$ \\
8th & Chinese Academy of Agricultural Sciences, China & $114(1.16)$ \\
9th & National Research Centre, Egypt & $110(1.12)$ \\
10th & Johns Hopkins Bloomberg School of Public Health, USA & $107(1.09)$
\end{tabular}

${ }^{a}$ Equal institutes have the same ranking number, and then a gap is left in the ranking numbers standardised 
among the largest contributors. This bibliometric analysis should be of interest to all governmental decisions, healthcare, industries, and educational institutions, involved in the ongoing advances in aflatoxin biosynthesis, better allocation of monitoring efforts, and improved management procedures.

\section{Supplementary information}

Supplementary information accompanies this paper at https://doi.org/10. 1186/s12995-019-0248-7.

Additional file 1. Trend of changes in number of publications for aflatoxin research (1963-2018)

\section{Abbreviations}

IFs: Impact factors; JCR: Journal Citation Reports; NIH: National Institutes of Health; SNIP: Source Normalized Impact per Paper; WoS: Web of Science

\section{Acknowledgements}

The author thanks retired British Library curator Andy Simons for English editing of the manuscript. Also, the author would like to thank An-Najah National University for all administrative support throughout the implementation of this project.

\section{Authors' contributions}

SZ conceptualised the study and formulated the study design, collected the data, analysed the data, interpreted the results, and drafted the manuscript. The author read and approved the final manuscript.

\section{Funding}

No funding was received for writing this study.

\section{Availability of data and materials}

Not applicable.

\section{Ethics approval and consent to participate}

Not applicable.

\section{Consent for publication}

Not applicable.

\section{Competing interests}

The author declares that he has no competing interests.

\section{Author details}

${ }^{1}$ Poison Control and Drug Information Center (PCDIC), College of Medicine and Health Sciences, An-Najah National University, Nablus 44839, Palestine. ${ }^{2}$ Department of Clinical and Community Pharmacy, College of Medicine and Health Sciences, An-Najah National University, Nablus 44839, Palestine.

${ }^{3}$ Clinical Research Centre, An-Najah National University Hospital, Nablus 44839, Palestine.

Received: 30 August 2019 Accepted: 13 November 2019

Published online: 21 November 2019

\section{References}

1. Kumar P, Mahato DK, Kamle M, Mohanta TK, Kang SG. Aflatoxins: a global concern for food safety, Human Health and Their Management. Front Microbiol. 2016:7:2170.

2. Wild CP, Gong YY. Mycotoxins and human disease: a largely ignored global health issue. Carcinogenesis. 2010;31(1):71-82

3. Ismail A, Goncalves BL, de Neeff DV, Ponzilacqua B, Coppa C, Hintzsche H, Sajid M, Cruz AG, Corassin CH, Oliveira CAF. Aflatoxin in foodstuffs: occurrence and recent advances in decontamination. Food Res Int. 2018; 113:74-85

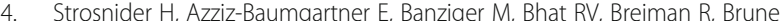
MN, DeCock K, Dilley A, Groopman J, Hell K, et al. Workgroup report: public health strategies for reducing aflatoxin exposure in developing countries. Environ Health Perspect. 2006:114(12):1898-903.

5. Williams JH, Phillips TD, Jolly PE, Stiles JK, Jolly CM, Aggarwal D. Human aflatoxicosis in developing countries: a review of toxicology, exposure, potential health consequences, and interventions. Am J Clin Nutr. 2004; 80(5):1106-22.

6. Wild CP. Aflatoxin exposure in developing countries: the critical interface of agriculture and health. Food Nutr Bull. 2007;28(2 Suppl):S372-80.

7. Ekundayo TC, Okoh Al. A global bibliometric analysis of Plesiomonas-related research (1990 - 2017). PLoS One. 2018;13(11):e0207655.

8. Al-Jabi SW. Global research trends in West Nile virus from 1943 to 2016: a bibliometric analysis. Glob Health. 2017;13(1):55.

9. Al-Jabi SW. Global trends in aspirin resistance-related research from 1990 to 2015: a Bibliometric analysis. Basic Clin Pharmacol Toxicol. 2017 121(6):512-9.

10. Li L, Ma X, Pandey S, Fan A, Deng X, Cui D. Bibliometric analysis of journals in the field of endoscopic Endonasal surgery for pituitary adenomas. J Craniofac Surg. 2018;29(1):e83-7.

11. Lopez-Munoz F, Tracy DK, Povedano-Montero FJ, Breedvelt J, Garcia-Pacios J, Fernandez-Martin MP, Rubio G, Alamo C. Trends in the scientific literature on atypical antipsychotic drugs in the United Kingdom: a bibliometric study. Ther Adv Psychopharmacol. 2019;9:2045125318820207.

12. Zhang J, Chen X, Gao X, Yang H, Zhen Z, Li Q, Lin Y, Zhao X. Worldwide research productivity in the field of psychiatry. Int J Ment Heal Syst. 2017; 11(1):20.

13. Nafade V, Nash M, Huddart S, Pande T, Gebreselassie N, Lienhardt C, Pai M. A bibliometric analysis of tuberculosis research, 2007-2016. PLoS One. 2018; 13(6):e0199706.

14. Hernandez-Vasquez A, Alarcon-Ruiz CA, Bendezu-Quispe G, Comande D, Rosselli D. A bibliometric analysis of the global research on biosimilars. J Pharm Policy Pract. 2018;11:6.

15. Ho Y-S, Siu E, Chuang K-Y. A bibliometric analysis of dengue-related publications in the science citation index expanded. Futur Virol. 2016;11(9): $631-48$

16. Srivastav AL, Kaur T, Rani L, Kumar A. Scientific research production of India and China in environmental chemistry: a bibliometric assessment. Int J Environ Sci Technol. 2019;16(8):4989-96.

17. Yang B, Huang $K$, Sun D, Zhang Y. Mapping the scientific research on nonpoint source pollution: a bibliometric analysis. Environ Sci Pollut Res Int. 2017;24(5):4352-66.

18. Zyoud $\mathrm{SH}$. Investigating global trends in paraquat intoxication research from 1962 to 2015 using bibliometric analysis. Am J Ind Med. 2018:61(6): $462-70$

19. Zyoud SH, Al-Jabi SW, Sweileh WM. Worldwide research productivity of paracetamol (acetaminophen) poisoning: a bibliometric analysis (20032012). Hum Exp Toxicol. 2015;34(1):12-23.

20. Zyoud SH, Al-Jabi SW, Sweileh WM, Awang R, Waring WS. Global research productivity of $\mathrm{N}$-acetylcysteine use in paracetamol overdose: a bibliometric analysis (1976-2012). Hum Exp Toxicol. 2015:34(10):1006-16.

21. Zyoud SH, Al-Jabi SW, Sweileh WM, Awang R, Waring WS. Bibliometric profile of the global scientific research on methanol poisoning (1902-2012). J Occup Med Toxicol. 2015;10:17.

22. Zyoud SH, Al-Jabi SW, Sweileh WM, Waring WS. Scientific research related to calcium channel blockers poisoning: Bibliometric analysis in Scopus, 19682012. Hum Exp Toxicol. 2015;34(11):1162-70.

23. Zyoud SH, Waring WS, Al-Jabi SW, Sweileh WM. Global research production in glyphosate intoxication from 1978 to 2015: a bibliometric analysis. Hum Exp Toxicol. 2017;36(10):997-1006.

24. Zyoud SH, Waring WS, Al-Jabi SW, Sweileh WM, Rahhal B, Awang R. Intravenous lipid emulsion as an antidote for the treatment of acute poisoning: a Bibliometric analysis of human and animal studies. Basic Clin Pharmacol Toxicol. 2016:119(5):512-9.

25. Guo K, Liu YF, Zeng C, Chen YY, Wei XJ. Global research on soil contamination from 1999 To 2012: a bibliometric analysis. Acta Agriculturae Scandinavica, Section B — Soil Plant Sc. 2014;64(5):377-91.

26. Blázquez-Ruiz J, Guerrero-Bote VP, Moya-Anegón F. New Scientometricbased knowledge map of food science research (2003 to 2014). Compr Rev Food Sci Food Saf. 2016:15(6):1040-55.

27. Kolle SR, Shankarappa TH. Publication trends in food-borne disease research (1991-2015): a web of science Core collection based analysis. J Agric Food Inform. 2016;18(1):53-63. 
28. Klingelhöfer D, Zhu Y, Braun M, Bendels MHK, Brüggmann D, Groneberg DA. Aflatoxin - publication analysis of a global health threat. Food Control. 2018;89:280-90.

29. Falagas ME, Pitsouni El, Malietzis GA, Pappas G. Comparison of PubMed, Scopus, web of science, and Google scholar: strengths and weaknesses. FASEB J. 2008;22(2):338-42

30. Kulkarni AV, Aziz B, Shams I, Busse JW. Comparisons of citations in web of science, Scopus, and Google scholar for articles published in general medical journals. Jama. 2009;302(10):1092-6.

31. Sweileh WM, Huijer HA, Al-Jabi SW, Zyoud SH, Sawalha AF. Nursing and midwifery research activity in Arab countries from 1950 to 2017. BMC Health Serv Res. 2019;19(1):340.

32. Sweileh WM, Wickramage K, Pottie K, Hui C, Roberts B, Sawalha AF, Zyoud $\mathrm{SH}$. Bibliometric analysis of global migration health research in peerreviewed literature (2000-2016). BMC Public Health. 2018;18(1):777.

33. Zyoud SH. Estimates of global research productivity in using nicotine replacement therapy for tobacco cessation: a bibliometric study. Glob Health. 2018;14(1):14

34. Zyoud SH, Sweileh WM, Awang R, Al-Jabi SW. Global trends in research related to social media in psychology: mapping and bibliometric analysis. Int J Ment Heal Syst. 2018;12:4

35. Zyoud SH, Waring WS, Al-Jabi SW, Sweileh WM. Global cocaine intoxication research trends during 1975-2015: a bibliometric analysis of web of science publications. Subst Abuse Treat Prev Policy. 2017;12(1):6.

36. Zyoud SH, Waring WS, Al-Jabi SW, Sweileh WM. Bibliometric profile of global scientific research on digoxin toxicity (1849-2015). Drug Chem Toxicol. 2018;18:1-7.

37. Al-Jabi SW. Arab world's growing contribution to global leishmaniasis research (1998-2017): a bibliometric study. BMC Public Health. 2019; 19(1):625.

38. Olisah C, Okoh OO, Okoh Al. A bibliometric analysis of investigations of polybrominated diphenyl ethers (PBDEs) in biological and environmental matrices from 1992-2018. Heliyon. 2018;4(11):e00964.

39. Sweileh WM, AbuTaha AS, Sawalha AF, Al-Khalil S, Al-Jabi SW, Zyoud SH. Bibliometric analysis of worldwide publications on multi-, extensively, and totally drug - resistant tuberculosis (2006-2015). Multidiscip Respir Med. 2016;11:45.

40. van Eck NJ, Waltman L. Software survey: VOSviewer, a computer program for bibliometric mapping. Scientometrics. 2010;84(2):523-38.

41. Butler WH. Investigation of aflatoxin poisoning. Food Cos Toxicol. 1963; 1(C):335.

42. Codner RC, Sargeant K, Yeo R. Production of aflatoxin by the culture of strains of Aspergillus flavus-oryzae on sterilized peanuts. Biotechnol Bioeng. 1963;5(3):185-92.

43. van Dorp DA, van Der Zijden ASM, Beerthuis RK, Sparreboom S, Ord WO, de Jong K, Keuning R. Dihydro-aflatoxin B, a metabolite of aspergillus flavus. Remarks on the structure of aflatoxin B. Recl Trav Chim Pays-Bas. 1963;82(6): 587-92.

44. Mongeon P, Paul-Hus A. The journal coverage of web of science and Scopus: a comparative analysis. Scientometrics. 2016;106(1):213-28.

45. Zyoud SH. Global research trends of Middle East respiratory syndrome coronavirus: a bibliometric analysis. BMC Infect Dis. 2016;16:255.

46. Briganti M, Delnevo CD, Brown L, Hastings SE, Steinberg MB. Bibliometric Analysis of Electronic Cigarette Publications: 2003(-)2018. Int J Environ Res Public Health. 2019:16(3):1

47. National Cancer Institute. Aflatoxins. 2018 [Cited 2019 March 23]; Available from: https://www.cancer.gov/about-cancer/causes-prevention/risk/ substances/aflatoxins

48. Koirala P, Kumar S, Yadav BK, Premarajan KC. Occurrence of aflatoxin in some of the food and feed in Nepal. Indian J Med Sci. 2005;59(8):331-6.

49. Lewis L, Onsongo M, Njapau H, Schurz-Rogers H, Luber G, Kieszak S, Nyamongo J, Backer L, Dahiye AM, Misore A, et al. Aflatoxin contamination of commercial maize products during an outbreak of acute aflatoxicosis in eastern and Central Kenya. Environ Health Perspect. 2005;113(12):1763-7.

50. Mohd-Redzwan S, Jamaluddin R, Abd-Mutalib MS, Ahmad Z. A mini review on aflatoxin exposure in Malaysia: past, present and future. Front Microbiol. 2013;4:334.

51. Wouters AT, Casagrande RA, Wouters F, Watanabe $\Pi$, Boabaid FM, Cruz $C E$, Driemeier D. An outbreak of aflatoxin poisoning in dogs associated with aflatoxin B1-contaminated maize products. J Vet Diagn Investig. 2013;25(2):282-7.
52. Oil Crops Research Institute of Chinese Academy of Agricultural Sciences. NSFC-CGIAR Cooperative Project on Groundnut Aflatoxin Resistance Supported. 2014 [Cited 2019 March 23]; Available from: http://ocri.caas.cn/ en/news/intlcooperation/90801.htm

53. Hou J, Wang G, Wang F, Cheng J, Ren H, Zhuang H, Sun J, Li L, Li J, Meng Q, et al. Guideline of prevention and treatment for chronic hepatitis B (2015 update). J Clin Transl Hepatol. 2017;5(4):297-318.

54. Sweileh WM, Al-Jabi SW, Zyoud SH, Sawalha AF, Abu-Taha AS. Global research output in antimicrobial resistance among uropathogens: a bibliometric analysis (2002-2016). J Glob Antimicrob Resist. 2018;13:104-14.

55. Zyoud SH. Global toxocariasis research trends from 1932 to 2015: a bibliometric analysis. Health Res Policy Syst. 2017;15(1):14.

56. Zyoud SH, Waring WS, Sweileh WM, Al-Jabi SW. Global research trends in Lithium toxicity from 1913 to 2015: a Bibliometric analysis. Basic Clin Pharmacol Toxicol. 2017:121(1):67-73.

57. Hamid AS, Tesfamariam IG, Zhang Y, Zhang ZG. Aflatoxin B1-induced hepatocellular carcinoma in developing countries: geographical distribution, mechanism of action and prevention. Oncol Lett. 2013;5(4):1087-92.

58. Giray B, Girgin G, Engin AB, Aydın S, Sahin G. Aflatoxin levels in wheat samples consumed in some regions of Turkey. Food Control. 2007;18(1): 23-9.

59. Baydar T, Engin AB, Girgin G, Aydin S, Sahin G. Aflatoxin and ochratoxin in various types of commonly consumed retail ground samples in Ankara, Turkey. Ann Agric Environ Med. 2005;12(2):193-7.

60. Kaleibar MT, Helan JA. A field outbreak of aflatoxicosis with high fatality rate in feedlot calves in Iran. Comp Clin Pathol. 2013;22(6):1155-63.

61. Chahota R, Katoch RC, Singh SP, Verma S, Mahajan A. Concurrent outbreak of chlamydiosis and aflatoxicosis among chickens in Himachal Pradesh, India. Veterinarski Arhiv. 2000;70(4):207-13.

62. Chahota R, Katoch RC, Singh SP, Verma S, Mahajan A, Nagal KB. Investigation of a severe aflatoxicosis outbreak among chicken in Himachal Pradesh. Indian J Anim Sci. 2000;70(1):22-4.

63. Sharma L, Srivastava B, Rana S, Sagar A, Dubey NK. Aflatoxins as serious threats to economy and health. In: Aflatoxins: Food Sources, Occurrence and Toxicological Effects; 2014. p. 259-86.

64. Reddy BN, Raghavender CR. Outbreaks of aflatoxicoses in India. Afr J Food Agric Nutr Dev. 2007;7(5):1-15.

65. Pierezan F, Oliveira Filho JC, Carmo PM, Lucena RB, Rissi DR, Togni M, Barros CSL. Outbreak of aflatoxicosis in calves in southern Brazil. Pesqui Vet Bras. 2010;30(5):418-22

66. Selim MI, Popendorf W, Ibrahim MS, el Sharkawy S, el Kashory ES. Aflatoxin B1 in common Egyptian foods. J AOAC Int. 1996;79(5):1124-9.

67. Magnussen A, Parsi MA. Aflatoxins, hepatocellular carcinoma and public health. World J Gastroenterol. 2013;19(10):1508-12.

68. Marin S, Ramos AJ, Cano-Sancho G, Sanchis V. Mycotoxins: occurrence, toxicology, and exposure assessment. Food Chem Toxicol. 2013;60:218-37.

69. Umesha S, Manukumar HM, Chandrasekhar B, Shivakumara P, Shiva Kumar J, Raghava S, Avinash P, Shirin M, Bharathi TR, Rajini SB, et al. Aflatoxins and food pathogens: impact of biologically active aflatoxins and their control strategies. J Sci Food Agric. 2017;97(6):1698-707.

70. Kamdem JP, Duarte AE, Lima KRR, Rocha JBT, Hassan W, Barros LM, Roeder T, Tsopmo A. Research trends in food chemistry: a bibliometric review of its 40 years anniversary (1976-2016). Food Chem. 2019;294:448-57.

71. Hussein HS, Brasel JM. Toxicity, metabolism, and impact of mycotoxins on humans and animals. Toxicology. 2001;167(2):101-34.

72. Bosch FX, Ribes J, Borras J. Epidemiology of primary liver cancer. Semin Liver Dis. 1999;19(3):271-85.

73. Machida M, Asai K, Sano M, Tanaka T, Kumagai T, Terai G, Kusumoto K, Arima T, Akita O, Kashiwagi $Y$, et al. Genome sequencing and analysis of Aspergillus oryzae. Nature. 2005:438(7071):1157-61.

74. Creppy EE. Update of survey, regulation and toxic effects of mycotoxins in Europe. Toxicol Lett. 2002;127(1-3):19-28.

75. Bosch FX, Ribes J, Cleries R, Diaz M. Epidemiology of hepatocellular carcinoma. Clin Liver Dis. 2005;9(2):191-211 v.

76. Placinta CM, D'Mello JPF, Macdonald AMC. A review of worldwide contamination of cereal grains and animal feed with Fusarium mycotoxins. Anim Feed Sci Technol. 1999;78(1):21-37.

77. Lunn RM, Langlois RG, Hsieh LL, Thompson CL, Bell DA. XRCC1 polymorphisms: effects on aflatoxin B1-DNA adducts and glycophorin a variant frequency. Cancer Res. 1999:59(11):2557-61.

78. Okuda K. Hepatocellular carcinoma. J Hepatol. 2000;32(1 Suppl):225-37. 
79. Whittaker S, Marais R, Zhu AX. The role of signaling pathways in the development and treatment of hepatocellular carcinoma. Oncogene. 2010 29(36):4989-5005.

80. El-Serag HB. Hepatocellular carcinoma: an epidemiologic view. J Clin Gastroenterol. 2002;35(5 Suppl 2):S72-8.

81. Richard JL. Some major mycotoxins and their mycotoxicoses--an overview. Int J Food Microbiol. 2007;119(1-2):3-10.

82. Yu J, Chang PK, Ehrlich KC, Cary JW, Bhatnagar D, Cleveland TE, Payne GA, Linz JE, Woloshuk CP, Bennett JW. Clustered pathway genes in aflatoxin biosynthesis. Appl Environ Microbiol. 2004;70(3):1253-62.

83. Turner NW, Subrahmanyam S, Piletsky SA. Analytical methods for determination of mycotoxins: a review. Anal Chim Acta. 2009;632(2):168-80.

84. D'Mello JPF, Placinta CM, Macdonald AMC. Fusarium mycotoxins: a review of global implications for animal health, welfare and productivity. Anim Feed Sci Technol. 1999:80(3):183-205.

85. McMahon BJ. The natural history of chronic hepatitis B virus infection. Hepatology. 2009:49(5 Suppl):S45-55.

86. Peraica M, Radic B, Lucic A, Pavlovic M. Toxic effects of mycotoxins in humans. Bull World Health Organ. 1999;77(9):754-66.

87. Gomaa Al, Khan SA, Toledano MB, Waked I, Taylor-Robinson SD Hepatocellular carcinoma: epidemiology, risk factors and pathogenesis. World J Gastroenterol. 2008:14(27):4300-8

88. Key TJ, Schatzkin A, Willett WC, Allen NE, Spencer EA, Travis RC. Diet, nutrition and the prevention of cancer. Public Health Nutr. 2004;7(1a): $187-200$.

89. Geiser DM, Pitt Jl, Taylor JW. Cryptic speciation and recombination in the aflatoxin-producing fungus Aspergillus flavus. Proc Natl Acad Sci U S A. 1998;95(1):388-93.

90. Guo X, Gao L, Wang Z, Feng C, Xing B. Top 100 Most-cited articles on pituitary adenoma: a Bibliometric analysis. World Neurosurg. 2018;116: e1153-67.

91. Nasir SAR, Gilani JA, Fatima K, Faheem U, Kazmi O, Siddiqi J, Khosa F. Top 100 Most-Cited Articles on Spontaneous Intracerebral Hemorrhage: A Bibliometric Analysis. World Neurosurg. 2018;110:445-449.e446.

92. Aznar-Sánchez JA, Velasco-Muñoz JF, Belmonte-Ureña LJ, ManzanoAgugliaro F. The worldwide research trends on water ecosystem services. Ecol Indic. 2019:99:310-23.

93. Zhang L, Gong J, Zhang Y. A review of ecosystem services: a bibliometric analysis based on web of science. Acta Ecol Sin. 2016:36:5967-77.

94. Hassan S-U, Haddawy P, Zhu J. A bibliometric study of the world's research activity in sustainable development and its sub-areas using scientific literature. Scientometrics. 2014;99(2):549-79.

95. Velasco-Muñoz J, Aznar-Sánchez J, Belmonte-Ureña L, López-Serrano M. Advances in water use efficiency in agriculture: a bibliometric analysis. Water. 2018;10(4):377.

96. Niu B, Loáiciga HA, Wang Z, Zhan FB, Hong S. Twenty years of global groundwater research: a science citation index expanded-based bibliometric survey (1993-2012). J Hydrol. 2014:519:966-75.

\section{Publisher's Note}

Springer Nature remains neutral with regard to jurisdictional claims in published maps and institutional affiliations.

Ready to submit your research? Choose BMC and benefit from:
- fast, convenient online submission
- thorough peer review by experienced researchers in your field
- rapid publication on acceptance
- support for research data, including large and complex data types
- gold Open Access which fosters wider collaboration and increased citations
- maximum visibility for your research: over 100M website views per year
At BMC, research is always in progress.
Learn more biomedcentral.com/submissions

